\title{
DIAGRAM UNIFIED MODELLING LANGUAGE UNTUK MEMODELKAN LAYANAN AUTOMATED TELLER MACHINE DENGAN PETRI NET
}

\author{
DORTEUS LODEWYIK RAHAKBAUW \\ Staf Jurusan Matematika FMIPA UNPATTI \\ Jl. Ir. M. Putuhena, Kampus Unpatti, Poka-Ambon, Maluku \\ e-mail: lodewyik@gmail.com
}

\begin{abstract}
ABSTRAK
Penelitian ini menguraikan suatu aplikasi yang mungkin dari Petri net untuk menspesifikasikan dinamika dari sistem informasi. Petri net adalah suatu alat matematik yang menerapkan spesifikasi formal dari dinamika sistim. Suatu prosedur yang formal disarankan karena mampu mentransformasi diagram kegiatan Unified Modeling Language (UML) ke dalam suatu model Petri net. Atas dasar perubahan bentuk ini dimungkinkan untuk memenuhi verifikasi model dinamis dari sistim riil, yaitu untuk mengevaluasi apakah aktivitas dan ordernya terdefinisi dengan baik (well defined). Ini juga mungkin untuk memecahkan permasalahan alur dan sinkronisasi aktivitas suatu sistim, seperti juga untuk mengoptimalkan model dinamis. Permasalahan yang dibahas dalam tulisan ini adalah bagaimana memodelkan layanan ATM dengan berdasar pada diagram aktivasi UML (Unified Modelling Language) dan bagaimana memodelkan layanan ATM (Automated Teller Machine) dengan menggunakan Petri Nets. Dihasilkan 49 Transisi dan 26 place untuk menggambarkan kedinamikan suatu ATM.
\end{abstract}

Kata kunci : Petri Net, ATM, UML

\section{PENDAHULUAN}

Petri net sebagai satu alat pelengkap untuk model aktivitas dari suatu sistim. Aktivitas digambarkan dalam satu diagram kegiatan UML (Unified Modeling Language) yaitu suatu diagram kegiatan menunjukkan interaksi antara objek, dalam kaitan dengan menggunakan istilah aktivitas. Aktivitas diwakili sebagai state action dan transisi-transisi antara state secara implisit dicetuskan oleh penyelesaian tindakan-tindakan di dalam sumber state.

Proses pengembangan dari suatu sistem informasi meliputi spesifikasi yang statis dan struktur yang dinamis dari suatu sistim. Dalam beberapa tahun terakhir suatu pendekatan berorientasi objek mempunyai dominan dalam pengembangan sistim informasi. Pendekatan itu didasarkan pada fakta bahwa objek dan hubunganhubungan tersebut mewakili karakteristik-karakteristik yang riil dari suatu sistim dalam suatu pengembangan. Sistim itulah yang menghubungkan suatu objek dengan objek yang lain dan saling menghubungkan. Tiap-tiap state dari sistem didefinisikan oleh state-state dari objek.

\section{TINJAUAN PUSTAKA}

\section{PETRI NET}

Petri net adalah suatu alat pemodelan matematik secara grafis. Dikembangkan pertama kali oleh C.A. Petri pada tahun 1962 [1], yang terdiri dari place-place, transisitransisi, dan anak panah yang menghubungkan place dan transisi. Arah masukan anak panah (arc) menghubungkan suatu input place ke transisi dan jika arah masuk anak panah bergerak dari suatu transisi maka akan berakhir pada output place . place dapat diisi dengan beberapa token. keadaan pada suatu sistem pemodelan ditandai dengan penomoran/tanda (tipe dari tiap token dapat dibedakan) pada setiap place. Transisi-transisi merupakan komponen aktif. Model aktivitas tersebut dapat terjadi ketika (transisi fires), kemudian mengubah keadaan dari sutu sIstem (penandaan dari Petri net). Transisi-transisi 
hanya dapat dikatakan fires jika berstatus enabled, (dalam artian setiap place mempunyai cukup token). Ketika transisi menembak, token pada input place akan berkurang dan ditambahkan pada output place yang dituju. Jumlah token yang berpindah bergantung pada bobot (weight) pada tiap-tiap arc.

Petri net adalah 4-tuple $(P, T, A, w)$ dengan

- $P$ : himpunan berhingga place, $P=\left\{p_{1}, p_{2}, \ldots, p_{n}\right\}$,

- $T$ : himpunan berhingga transisi, $T=\left\{t_{1}, t_{2}, \ldots, t_{m}\right\}$,

- $A$ : himpunan arc, $A \subseteq(P \times T) \cup(T \times P)$

- $\omega$ : fungsi bobot, $\omega: \mathrm{A} \rightarrow\{1,2,3, \ldots\}$

maka himpunan place dan transisi tidak harus berupa himpunan berhingga melainkan bisa berupa himpunan takhingga.

\section{HASIL DAN PEMBAHASAN}

\section{DIAGRAM AKTIVITAS}

Diagram aktivitas adalah sesuatu yang khusus dalam diagram statechart dari UML di mana semua state adalah suatu tindakan, dan transisi-transisi itu tentukan oleh penyelesaian tindakan-tindakan dalam sumber state. Diagram aktivitas berhubungan dengan suatu kelas, untuk mengimplementasikan suatu operasi yang terjadi pada kelas/suatu kasus. Tujuan dari diagram adalah ini difokuskan pada alur suatu control dan pembawa data oleh proses internal.

State action adalah suatu keadaan dengan tindakan internal dan sedikitnya satu transisi yang berperan dalam setiap tindakan internal . Jika ada beberapa transisi yang dapat digunakan maka transisi-transisi tersebut harus mempunyai kondisi bersyarat. state action digunakan untuk memodelkan setiap langkah dalam tiap eksekusi dari suatu algoritma atau prosedur. Setiap keputusan menyatakan situasi ketika kondisi bersyarat digunakan untuk menandai ada tidaknya transisi-transisi yang mungkin. Transisi-transisi tersebut disebut transisi keluaran, dan transisi-transisi lain disebut transisi masukan.

Perubahan bentuk tiap-tiap sesi dari diagram aktivitas Unified Modeling Language ke dalam suatu model Petri net perlu dipertimbangkan. Perubahan bentuk state aktivitas, transisi-transisi dan keputusan-keputusan yang internal digambarkan dengan cara yang formal. Dengan demikian suatu definisi dari diagram aktivitas serta sruktur dari petri net dapat terjawab.

Lebih lanjut, suatu transisi yang kompleks mungkin mempunyai sumber state aktivitas dan targetnya. Hal ini merepresentasi sinkronisasi dan/ atau pemisahan kendali ke dalam alur-alur secara berbarengan. Suatu transisi kompleks dikatakan enabled ketika semua state dapat terlewati. Transisi kompleks yang menunjukkan sinkronisasi disebut join, dan yang menunjukkan pemisahan disebut fork.

\section{MENTRANSFORMASIKAN STATE AKTIVITAS DAN TRANSISI-TRANSISI INTERNAL KE DALAM SUATU MODEL PETRI NET .}

Perubahan bentuk diagram aktivitas ke dalam suatu model Petri net didasarkan pada perubahan bentuk perintah yang ditunjukkan dalam gambar 1-3. Gambar 1 menunjukkan aturan berhubungan dengan perubahan bentuk dari suatu state aktivitas dan menyertakan transisi-transisi masukan dan keluaran yang internal. State aktivitas $\mathrm{s}_{\mathrm{i}}$ diubah menjadi $s_{i}$ transisi dari suatu Petri net. Suatu transisi masukan $\mathrm{a}_{\mathrm{i}}$ dari state aktivitas $\mathrm{s}_{\mathrm{i}}$ diubah menjadi place masukan $a_{i}$ dari $s_{i}$ transisi diubah menjadi tempat masukan $a_{i}$ dari transisi $s_{i}$ suatu Petri net. Transisi keluaran $\mathrm{a}_{\mathrm{k}}$ dari state aktivitas $\mathrm{s}_{\mathrm{i}}$ diubah menjadi tempat keluaran $\mathrm{a}_{\mathrm{k}}$ dari transisi $\mathrm{s}_{\mathrm{i}}$ dari suatu Petri net.

Perubahan bentuk suatu keputusan dan menyertakan transisi-transisi masukan dan keluaran dari diagram aktivitas ke dalam place-place dan transisi-transisi suatu Petri net ditunjukkan di dalam gambar 2. Transisi masukan $\mathrm{a}_{\mathrm{i}}$ diubah menjadi place masukan $\mathrm{a}_{\mathrm{i}}$ dan transisitransisi keluaran $\mathrm{a}_{\mathrm{j}}$ dan $\mathrm{a}_{\mathrm{k}}$ diubah menjadi place keluaran $\mathrm{a}_{\mathrm{k}}$ dan $\mathrm{a}_{\mathrm{j}}$ dari suatu Petri net. Suatu keputusan ditunjukkan dengan dua atau lebih transisi. Banyaknya transisi-transisi pada suatu Petri net sama banyaknya dengan transisitransisi keluaran pada suatu keputusan.

Diagram aktivitas dengan transisi keluaran lebih dari satu dapat diperagakan seperti yang ditunjukkan di dalam gambar 3. State Aktivitas menyatakan $\mathrm{s}_{\mathrm{i}}$ dimodelkan dengan

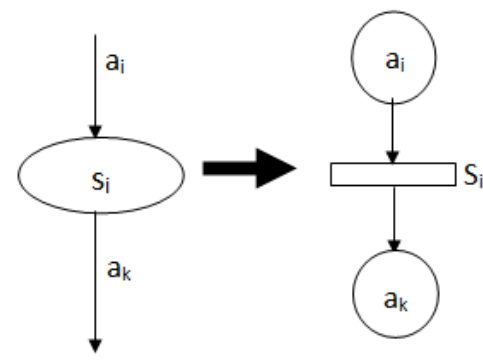

Gambar 1: Perubahan bentuk perintah untuk satu state aktivitas

state aktivitas $\mathrm{s}_{\mathrm{i}}{ }^{\prime}$ dan keputusan $\mathrm{d}_{\mathrm{l}}$, yang dihubungkan dengan transisi $\mathrm{a}_{\mathrm{i}}{ }^{\prime}$. transisi masukan $\mathrm{a}_{\mathrm{i}}$ dari state aktivitas $\mathrm{s}_{\mathrm{i}}$ menjadi transisi masukan dari state aktivitas $\mathrm{s}_{\mathrm{i}}{ }^{\prime}$.

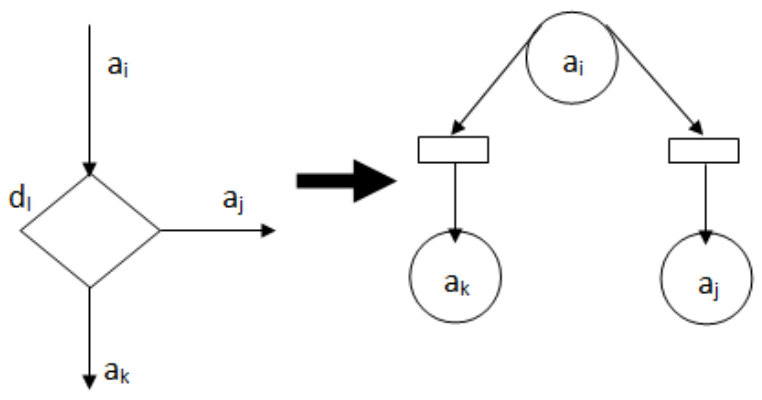

Gambar 2: Perubahan bentuk perintah untuk suatu keputusan

transisi-transisi keluaran $\mathrm{a}_{\mathrm{j}}$ dan $\mathrm{a}_{\mathrm{k}}$ menjadi transisi-transisi keluaran keputusan $\mathrm{d}_{1}$ '. struktur ini dapat diubah menjadi suatu Petri net menurut aturan menggambar di atas yang ditunjukkan oleh gambar-gambar 1 dan 2 . 


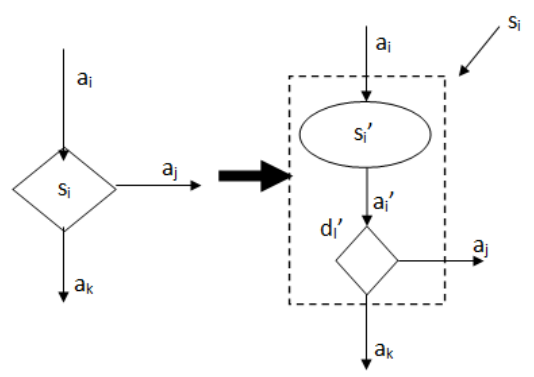

Gambar 3: Perubahan bentuk memerintah karena state aktivitas dengan sisa transisi lebih dari satu

\section{CONTOH ILUSTRASI}

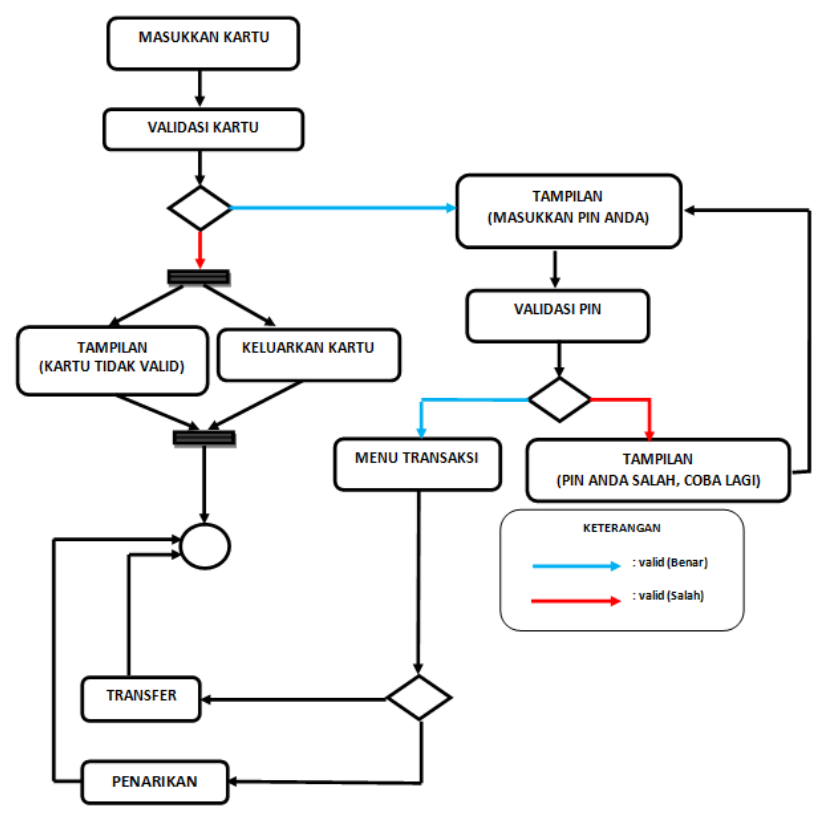

Gambar 4 : Diagram aktivitas untuk mesin ATM

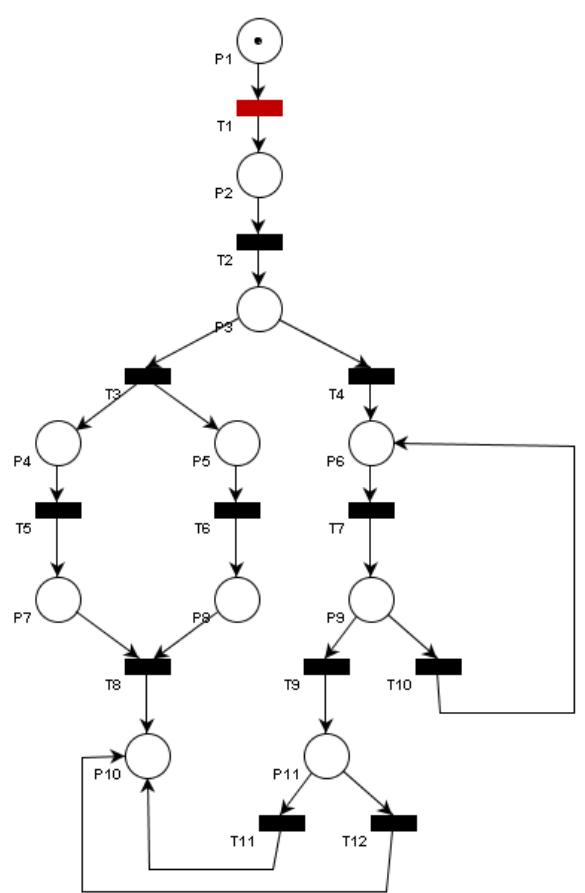

Gambar 5 : Model Petri net dari Diagram aktivitas pada Gambar 4

\section{3 kasus.}

1. Kartu valid PIN valid

2. Kartu tidak valid

3. Kartu valid PIN tidak valid

Matriks forward incidence.

$$
\left[\begin{array}{llllllllllll}
0 & 0 & 0 & 0 & 0 & 0 & 0 & 0 & 0 & 0 & 0 & 0 \\
1 & 0 & 0 & 0 & 0 & 0 & 0 & 0 & 0 & 0 & 0 & 0 \\
0 & 1 & 0 & 0 & 0 & 0 & 0 & 0 & 0 & 0 & 0 & 0 \\
0 & 0 & 1 & 0 & 0 & 0 & 0 & 0 & 0 & 0 & 0 & 0 \\
0 & 0 & 1 & 0 & 0 & 0 & 0 & 0 & 0 & 0 & 0 & 0 \\
0 & 0 & 0 & 1 & 0 & 0 & 0 & 0 & 0 & 1 & 0 & 0 \\
0 & 0 & 0 & 0 & 1 & 0 & 0 & 0 & 0 & 0 & 0 & 0 \\
0 & 0 & 0 & 0 & 0 & 1 & 0 & 0 & 0 & 0 & 0 & 0 \\
0 & 0 & 0 & 0 & 0 & 0 & 1 & 0 & 0 & 0 & 0 & 0 \\
0 & 0 & 0 & 0 & 0 & 0 & 0 & 1 & 0 & 0 & 1 & 1 \\
0 & 0 & 0 & 0 & 0 & 0 & 0 & 0 & 1 & 0 & 0 & 0
\end{array}\right]
$$

\section{Matriks Backward incidence.}

$$
\left[\begin{array}{llllllllllll}
1 & 0 & 0 & 0 & 0 & 0 & 0 & 0 & 0 & 0 & 0 & 0 \\
0 & 1 & 0 & 0 & 0 & 0 & 0 & 0 & 0 & 0 & 0 & 0 \\
0 & 0 & 1 & 1 & 0 & 0 & 0 & 0 & 0 & 0 & 0 & 0 \\
0 & 0 & 0 & 0 & 1 & 0 & 0 & 0 & 0 & 0 & 0 & 0 \\
0 & 0 & 0 & 0 & 0 & 1 & 0 & 0 & 0 & 0 & 0 & 0 \\
0 & 0 & 0 & 0 & 0 & 0 & 1 & 0 & 0 & 0 & 0 & 0 \\
0 & 0 & 0 & 0 & 0 & 0 & 0 & 1 & 0 & 0 & 0 & 0 \\
0 & 0 & 0 & 0 & 0 & 0 & 0 & 1 & 0 & 0 & 0 & 0 \\
0 & 0 & 0 & 0 & 0 & 0 & 0 & 0 & 1 & 1 & 0 & 0 \\
0 & 0 & 0 & 0 & 0 & 0 & 0 & 0 & 0 & 0 & 0 & 0 \\
0 & 0 & 0 & 0 & 0 & 0 & 0 & 0 & 0 & 0 & 1 & 1
\end{array}\right]
$$

Keadaan awal petri net

$$
\mathrm{X}_{0}=\left[\begin{array}{llllllllll}
1 & 0 & 0 & 0 & 0 & 0 & 0 & 0 & 0 & 0
\end{array}\right]^{T}
$$

\section{Kartu Valid Pin Valid}

$$
\begin{aligned}
& X_{1}=\left[\begin{array}{lllllllllll}
0 & 1 & 0 & 0 & 0 & 0 & 0 & 0 & 0 & 0 & 0
\end{array}\right]^{T} \\
& \mathrm{X}_{2}=\left[\begin{array}{lllllllllll}
0 & 0 & 1 & 0 & 0 & 0 & 0 & 0 & 0 & 0 & 0
\end{array}\right]^{T}
\end{aligned}
$$

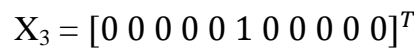

$$
\begin{aligned}
& \mathrm{X}_{4}=\left[\begin{array}{lllllllllll}
0 & 0 & 0 & 0 & 0 & 0 & 0 & 0 & 1 & 0 & 0
\end{array}\right]^{T} \\
& \mathrm{X}_{5}=\left[\begin{array}{lllllllllll}
0 & 0 & 0 & 0 & 0 & 0 & 0 & 0 & 0 & 0 & 1
\end{array}\right]^{T} \\
& \mathrm{X}_{6}=\left[\begin{array}{lllllllllll}
0 & 0 & 0 & 0 & 0 & 0 & 0 & 0 & 0 & 1 & 0
\end{array}\right]^{T}
\end{aligned}
$$

Dengan susunan transisi yang di fire secara berurutan adalah: $T_{1}, T_{2}, T_{4}, T_{7}, T_{9}, T_{10}$ 
2. Kartu tidak valid

$$
\begin{aligned}
& X_{1}=\left[\begin{array}{lllllllllll}
0 & 1 & 0 & 0 & 0 & 0 & 0 & 0 & 0 & 0 & 0
\end{array}\right]^{T} \\
& X_{2}=\left[\begin{array}{lllllllllll}
0 & 0 & 1 & 0 & 0 & 0 & 0 & 0 & 0 & 0 & 0
\end{array}\right]^{T} \\
& X_{3}=\left[\begin{array}{lllllllllll}
0 & 0 & 0 & 1 & 1 & 0 & 0 & 0 & 0 & 0 & 0
\end{array}\right]^{T} \\
& X_{4}=\left[\begin{array}{lllllllllll}
0 & 0 & 0 & 0 & 1 & 0 & 1 & 0 & 0 & 0 & 0
\end{array}\right]^{T} \\
& X_{5}=\left[\begin{array}{lllllllllll}
0 & 0 & 0 & 0 & 0 & 0 & 1 & 1 & 0 & 0 & 0
\end{array}\right]^{T} \\
& X_{6}=\left[\begin{array}{lllllllllll}
0 & 0 & 0 & 0 & 0 & 0 & 0 & 0 & 0 & 1 & 0
\end{array}\right]^{T}
\end{aligned}
$$

Dengan susunan transisi yang di fire secara berurutan adalah: $T_{1}, T_{2}, T_{3}, T_{5}, T_{6}, T_{8}$

\section{Kartu valid PIN tidak valid}

$$
\begin{aligned}
& X_{1}=\left[\begin{array}{lllllllllll}
0 & 1 & 0 & 0 & 0 & 0 & 0 & 0 & 0 & 0 & 0
\end{array}\right]^{T} \\
& X_{2}=\left[\begin{array}{lllllllllll}
0 & 0 & 1 & 0 & 0 & 0 & 0 & 0 & 0 & 0 & 0
\end{array}\right]^{T} \\
& X_{3}=\left[\begin{array}{lllllllllll}
0 & 0 & 0 & 0 & 0 & 1 & 0 & 0 & 0 & 0 & 0
\end{array}\right]^{T} \\
& X_{4}=\left[\begin{array}{llllllllllll}
0 & 0 & 0 & 0 & 0 & 0 & 0 & 0 & 1 & 0 & 0
\end{array}\right]^{T} \\
& X_{5}=\left[\begin{array}{lllllllllll}
0 & 0 & 0 & 0 & 0 & 1 & 0 & 0 & 0 & 0 & 0
\end{array}\right]^{T} \\
& X_{6}=\left[\begin{array}{lllllllllll}
0 & 0 & 0 & 0 & 0 & 0 & 0 & 0 & 1 & 0 & 0
\end{array}\right]^{T}
\end{aligned}
$$

Ket: Yang di tandai kurung kurawal berulang. Dengan susunan transisi yang di fire secara berurutan adalah : $T_{1}, T_{2}, T_{4}, T_{7}, T_{10}, T_{7}, T_{10}, \ldots$

\section{Coverability tree}

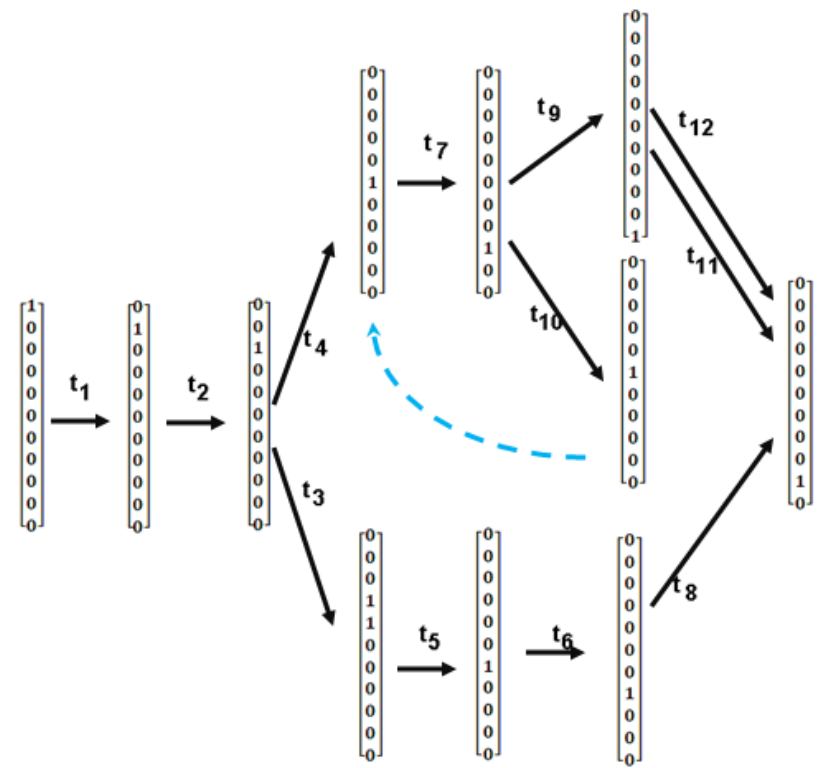

Tahap pertama yang dilakukan dalam membangun coverability tree adalah menentukan node root. Node root menyatakan keadaan awal Petri net yaitu

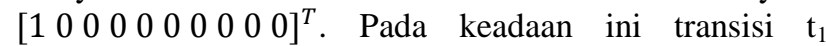
enabled dengan memfire transisi ini keadaan Petri net menjadi $\left[\begin{array}{lllllllllll}0 & 1 & 0 & 0 & 0 & 0 & 0 & 0 & 0 & 0 & 0\end{array}\right]^{T}$ transisi yang enabled pada keadaan ini adalah $\mathrm{t}_{2}$, dan keadaan Petri net menjadi

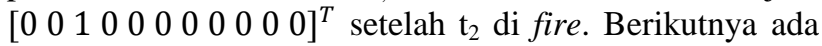
dua transisi yang enabled yaitu $t_{3}$ dan $t_{4}$ dan apabila $t_{3}$ difire maka keadaan Petri net menjadi $\left[\begin{array}{llllllllll}0 & 0 & 0 & 1 & 1 & 0 & 0 & 0 & 0 & 0\end{array}\right]^{T}$, pada keadaan ini $t_{5}$ dan $t_{6}$ enabled dan bila dilakukan pemfirean berturut turut $\mathrm{t}_{5}, \mathrm{t}_{6}$ maka didapat juga keadaan Petri net secara berturut-turut adalah $\left[\begin{array}{lllllllllll}0 & 0 & 0 & 0 & 1 & 0 & 1 & 0 & 0 & 0 & 0\end{array}\right]^{T},\left[\begin{array}{lllllllllll}0 & 0 & 0 & 0 & 0 & 0 & 1 & 1 & 0 & 0 & 0\end{array}\right]^{T}$, sekarang pada keadaan Petri net $\left[\begin{array}{llllllllll}0 & 0 & 0 & 0 & 0 & 0 & 1 & 1 & 0 & 0\end{array}\right]^{T}$ transisi yang enabled hanya $\mathrm{t}_{8}$ dan bila di lakukan pemfirean didapat keadaan akhir Petri net adalah $\left[\begin{array}{llllllllll}0 & 0 & 0 & 0 & 0 & 0 & 0 & 0 & 0 & 1\end{array}\right]^{T}$. Selanjutnya pada saat keadaan

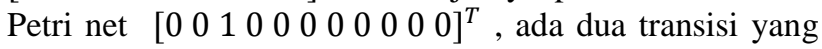
enabled yaitu $\mathrm{t}_{3}$ dan $\mathrm{t}_{4}$. Sudah dilakukan pemfirean untuk $\mathrm{t}_{3}$ dan apabila dilakukan pemfirean untuk $\mathrm{t}_{4}$ akan merubah keadan Petri net menjadi $\left[\begin{array}{lllllllllll}0 & 0 & 0 & 0 & 0 & 1 & 0 & 0 & 0 & 0 & 0\end{array}\right]^{T}$, sekarang satu-satunya transisi yang enabled adalah $\mathrm{t}_{7}$ dan keadaan Petri net menjadi $\left[\begin{array}{llllllllll}0 & 0 & 0 & 0 & 0 & 0 & 0 & 0 & 1 & 0\end{array}\right]^{T}$ setelah $\mathrm{t}_{7}$ difire. Sekarang ada $\mathrm{t}_{9}$ dan $\mathrm{t}_{10}$ yang enabled dan apabila $\mathrm{t}_{10}$ difire akan kembali ke keadaan Petri net saat $\left[\begin{array}{lllllllllll}0 & 0 & 0 & 0 & 0 & 1 & 0 & 0 & 0 & 0 & 0\end{array}\right]^{T}$, sedangkan apabila $t_{9}$ yang difire maka akan merubah keadaan Petri net menjadi $\left[\begin{array}{llllllllll}0 & 0 & 0 & 0 & 0 & 0 & 0 & 0 & 0 & 0\end{array}\right]^{T}$ sekarang ada dua transisi yang enabled yaitu $\mathrm{t}_{11}$ dan $\mathrm{t}_{12}$ dan walaupun salah satunya difire tetap akan merubah keadaan akhir Petri net menjadi $\left[\begin{array}{lllllllllll}0 & 0 & 0 & 0 & 0 & 0 & 0 & 0 & 0 & 1 & 0\end{array}\right]^{T}$.

\section{SIMULASI LAYANAN PADA ATM (AUTOMATED TELLER MACHINE) BNI}

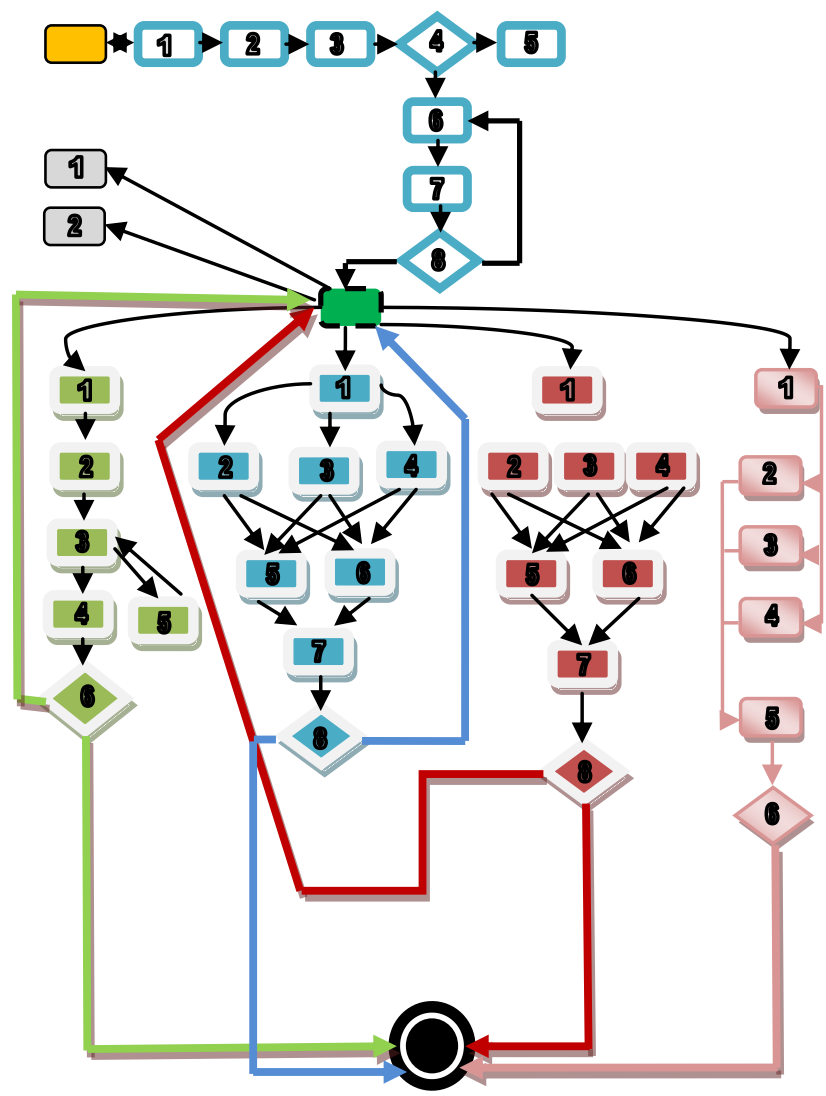

Gambar 6 : Diagram aktivitas untuk mesin ATM BNI 
Tabel 1.

Keterangan Transisi dari petri net pada Gambar 6

\begin{tabular}{|c|c|c|}
\hline No & $\begin{array}{c}\text { Kode } \\
\text { Transisi }\end{array}$ & Keterangan \\
\hline 1 & $\mathrm{~T}_{0}$ & Nasabah masuk ke ATM \\
\hline 2 & $\mathrm{~T}_{1}$ & Nasabah memasukkan kartu ATM \\
\hline 3 & $\mathrm{~T}_{2}$ & Validasi kartu \\
\hline 4 & $\mathrm{~T}_{3}$ & Kartu tidak valid \\
\hline 5 & $\mathrm{~T}_{4}$ & Kartu valid \\
\hline 6 & $\mathrm{~T}_{5}$ & Nasabah memasukkan PIN \\
\hline 7 & $\mathrm{~T}_{6}$ & Validasi PIN \\
\hline 8 & $\mathrm{~T}_{7}$ & PIN tidak valid \\
\hline 9 & $\mathrm{~T}_{8}$ & PIN valid \\
\hline 10 & $\mathrm{~T}_{9}$ & GANTI PIN \\
\hline 11 & $\mathrm{~T}_{10}$ & Registrasi PIN lama \\
\hline 12 & $\mathrm{~T}_{11}$ & Registrasi PIN baru \\
\hline 13 & $\mathrm{~T}_{12}$ & Format PIN salah \\
\hline 14 & $\mathrm{~T}_{13}$ & Pembatalan Ganti PIN \\
\hline 15 & $\mathrm{~T}_{14}$ & Stop transaksi \\
\hline 16 & $\mathrm{~T}_{15}$ & Transaksi lain \\
\hline 17 & $\mathrm{~T}_{16}$ & TRANSFER \\
\hline 18 & $\mathrm{~T}_{17}$ & Pembatalan transfer \\
\hline 19 & $\mathrm{~T}_{18}$ & Dari rekening giro \\
\hline 20 & $\mathrm{~T}_{19}$ & Dari rekening tabungan \\
\hline 21 & $\mathrm{~T}_{20}$ & Dari kartu kredit \\
\hline 22 & $\mathrm{~T}_{21}$ & Ke rekening bank lain \\
\hline 23 & $\mathrm{~T}_{22}$ & Ke rekening BNI \\
\hline 24 & $\mathrm{~T}_{23}$ & Masukkan no rekening bank lain \\
\hline 25 & $\mathrm{~T}_{24}$ & Masukkan no rekening BNI \\
\hline 26 & $\mathrm{~T}_{25}$ & Stop transaksi \\
\hline 27 & $\mathrm{~T}_{26}$ & Transaksi lain \\
\hline 28 & $\mathrm{~T}_{27}$ & PEMBAYARAN \\
\hline 29 & $\mathrm{~T}_{28}$ & REGISTRASI e-CHANEL \\
\hline 30 & $\mathrm{~T}_{29}$ & PENARIKKAN TUNAI \\
\hline 31 & $\mathrm{~T}_{30}$ & Dari rekening giro \\
\hline 32 & $\mathrm{~T}_{31}$ & Dari rekening tabungan \\
\hline 33 & $\mathrm{~T}_{32}$ & Dari kartu kredit \\
\hline 34 & $\mathrm{~T}_{33}$ & Lainnya \\
\hline 35 & $\mathrm{~T}_{34}$ & Salah masukkan nominal \\
\hline 36 & $\mathrm{~T}_{35}$ & Masukkan nominal sudah benar \\
\hline 37 & $\mathrm{~T}_{36}$ & Nominal 250.000 \\
\hline 38 & $\mathrm{~T}_{37}$ & Nominal 500.000 \\
\hline 39 & $\mathrm{~T}_{38}$ & Nominal 1.000 .000 \\
\hline 40 & $\mathrm{~T}_{39}$ & Nominal 1.200 .000 \\
\hline 41 & $\mathrm{~T}_{40}$ & Pengambilan dengan bukti struk \\
\hline 42 & $\mathrm{~T}_{41}$ & Pengambilan tanpa bukti struk \\
\hline 43 & $\mathrm{~T}_{42}$ & INFORMASI SALDO \\
\hline 44 & $\mathrm{~T}_{43}$ & Rekening giro \\
\hline 45 & $\mathrm{~T}_{44}$ & Rekening tabungan \\
\hline 46 & $\mathrm{~T}_{45}$ & Kartu kredit \\
\hline 47 & $\mathrm{~T}_{46}$ & Transaksi lain \\
\hline 48 & $\mathrm{~T}_{47}$ & Stop transaksi \\
\hline 49 & $\mathrm{~T}_{48}$ & Pengambilan kartu \\
\hline 50 & $\mathrm{~T}_{49}$ & Pengambilan struk \\
\hline
\end{tabular}

Tabel 2.

Keterangan Place dari petri net pada Gambar 6

\begin{tabular}{|l|c|l|}
\hline No & $\begin{array}{c}\text { Kode } \\
\text { Transisi }\end{array}$ & \multicolumn{1}{c|}{ Keterangan } \\
\hline 1 & $\mathrm{P}_{0}$ & Antrian nasabah \\
\hline 2 & $\mathrm{P}_{1}$ & Nasabah didalam ATM \\
\hline 3 & $\mathrm{P}_{2}$ & Kartu masuk ATM \\
\hline 4 & $\mathrm{P}_{3}$ & Proses validasi kartu ATM \\
\hline 5 & $\mathrm{P}_{4}$ & $\begin{array}{l}\text { Kartu yang tidak valid di tampung di } \\
\text { ATM }\end{array}$ \\
\hline 6 & $\mathrm{P}_{5}$ & Kartu valid \\
\hline 7 & $\mathrm{P}_{6}$ & Menu masukkan PIN \\
\hline 8 & $\mathrm{P}_{7}$ & Proses validasi PIN \\
\hline 9 & $\mathrm{P}_{8}$ & Tampilan menu utama \\
\hline 10 & $\mathrm{P}_{9}$ & Masukkan PIN lama \\
\hline 11 & $\mathrm{P}_{10}$ & Masukkan PIN baru \\
\hline 12 & $\mathrm{P}_{11}$ & Menu mau lanjut transaksi atau tidak \\
\hline 13 & $\mathrm{P}_{12}$ & Menu tampilan Transfer \\
\hline 14 & $\mathrm{P}_{13}$ & Pilih transfer ke Rek.BNI / bank lain \\
\hline 15 & $\mathrm{P}_{14}$ & Masukkan no rek bank lain \\
\hline 16 & $\mathrm{P}_{15}$ & Masukkan no rek BNI \\
\hline 17 & $\mathrm{P}_{16}$ & Menu mau lanjut transaksi atau tidak \\
\hline 18 & $\mathrm{P}_{17}$ & Menu PEMBAYARAN \\
\hline 19 & $\mathrm{P}_{18}$ & Menu Reg. e-channel \\
\hline 20 & $\mathrm{P}_{19}$ & Menu transaksi arah penarikan \\
\hline 21 & $\mathrm{P}_{20}$ & Nominal transaksi penarikan \\
\hline 22 & $\mathrm{P}_{21}$ & $\begin{array}{l}\text { Input Nominal yang tidak ada pada } \\
\text { menu }\end{array}$ \\
\hline 23 & $\mathrm{P}_{22}$ & Mau cetak receipt atau tidak \\
\hline 24 & $\mathrm{P}_{23}$ & Proses cetak receipt \\
\hline 25 & $\mathrm{P}_{24}$ & Menu arah informasi saldo \\
\hline 26 & $\mathrm{P}_{25}$ & Jumlah Saldo, mau Transaksi lain \\
\hline 27 & $\mathrm{P}_{26}$ & $\begin{array}{l}\text { Terima kasih sudah melakukan } \\
\text { transaksi }\end{array}$ \\
\hline
\end{tabular}

\section{KESIMPULAN}

1. Petri net mampu merepresentasikan cara kerja mesin ATM dengan 49 Transisi dan 26 Place.

2. Dalam pengembangan sistem yang lebih besar sekalipun sepertii ATM Petri net mampu merepresentasikan selama sistem bersifat tidak deadlock

\section{DAFTAR PUSTAKA}

Adzkiya, D. 2008, Membangun Petri Net Lampu Lalu Lintas dan Simulasinya,Tesis Magister, Institut Teknologi Sepuluh Nopember, Surabaya.

Bordbar, B., Giacomini, L., Holding, D.J., Design Of Distributed Manufacturing Systems Using Uml And Petri Nets, Department of Electronic Engineering, School of Engineering, Aston University, Aston Triangle, Birmingham. 
David, R. dan Alla, H. 2005, Discrete, Continuous, and Hybrid Petri Nets, Springer-Verlag Berlin Heidelberg, New York.

Saldhana, J.A., Shatz, S.M., UML Diagrams to Object Petri Net Models: An Approach for Modeling and Analysis, Department of Electrical Engineering and Computer Science University of Illinois, Chicago.

Storrle, H, Models of Software Architecture, Fakult"at f'ur Mathematik und Informatik LudwigMaximilians-Universit" at M"unchen 